\title{
John Keats at Winchester
}

\section{Nicholas Roe}

John Keats was at Winchester on at least three occasions. He was aboard the Southampton coach when it called there early in the morning of 15 April 1817, and he passed through again, a week later, on his way back to London. On 12 August 1819, after summering at the Isle of Wight, he came to Winchester to find 'a tolerable Librarry' ( $L J K$, II, 147) and this time he stayed for two full months. Keats's visits to Winchester bookend his rapid development as a poet: in the spring of 1817 he was beginning his 'poetic romance' Endymion - a work that Keats himself described as 'adolescent'; in 1819 he was here as the poet of Lamia, 'La Belle Dame sans Merci', The Eve of St Agnes and, composed after a Sunday walk at Winchester, 'To Autumn'. So Winchester witnessed Keats becoming a poet of genius, and we know what he thought about Winchester because he wrote a good deal about the city.

'This Winchester is a fine place', Keats told Fanny Brawne, mentioning the city's 'beautiful Cathedral and many other ancient building[s]'. He had swapped his 'little coffin of a room' at Shanklin for 'a large room - where I can promenade at my pleasure - looks out onto a beautiful - blank side of a house - It is strange I should like it better than the view of the sea from our window at Shanklin ...' (LJK, II, 141). Fanny heard that the air at Winchester was bracing: 
Since I have been at Winchester I have been improving in health - it is not so confined - and there is on one side of the city a dry chalky down where the air is worth six pence a pint ...

$$
\text { (LJK, II, 156) }
$$

- and that Winchester was historical:

There is a fine Cathedrall which to me is always a source of amusement; part of it built 1400 years ago; and the more modern by a magnificent Man, you may have read of in our History, called William of Wickham. The whole town is beautifully wooded - From the Hill at the eastern extremity you see a prospect of Streets, and old Buildings mixed up with Trees - Then There are the most beautiful streams about I ever saw - full of Trout - There is the Foundation of St Croix about half a mile in the fields ... - We have a Collegiate School, a roman catholic School; a chapel ditto and a Nunnery! And what improves it all is, the fashionable inhabitants are all gone to Southampton.

$$
\text { (LJK, II, 147-8) }
$$

At Winchester there were no tourists, he reported to Fanny, so he enjoyed a daily walk across the water meadows:

I go out at the back gate across one street, into the Cathedral yard, which is always interesting; then I pass under the trees along a paved path, pass the beautiful front of the Cathedral, turn to the left under a stone door way - then I am on the other side of the building - which leaving behind me I pass on 
through two college-like squares seemingly built for the dwelling place of Deans and Prebendaries - garnished with grass and shaded with trees. Then I pass through one of the old city gates and then you are in one College-Street through which I pass and at the end thereof crossing some meadows and at last a country alley of gardens I arrive... at the foundation of Saint Cross, which is a very interesting old place.

(LJK, II, 209)

Winchester offered Keats beauty, antiquity, health, history, landscape and a seventh-century cathedral. ${ }^{1}$ Its literary associations included Joseph Warton, headmaster of the College and poet of The Enthusiast and 'Ode to Fancy'; Warton's student, William Lisle Bowles, was the author of Fourteen Sonnets (1789) among them 'To the River Itchin, near Winton' (i.e. near Winchester). Winchester offered everything, one might almost say, except a library: Winchester College and its library were apparently not open to Keats, but otherwise he was free to wander among woods, streets, trees, and streams: 'I go out ... then I pass under ... turn ... leave behind me ... pass on ... pass through ... and at last ... I arrive'.

\section{PRINTER: Ch 2, Fig 1 TO GO NEAR HERE}

CAPTION Fig 1. 'I pass under the trees along a paved path, pass the beautiful front of the Cathedral, turn to the left under a stone door way-then I am on the other side of the building'. Keats's stone door on the south side of Winchester cathedral, seen here in September 2009. Author's photograph 
CAPTION Fig. 2. The Inner Quadrangle of St Cross Hospital, Winchester. The buildings seen here are, from left to right, Beaufort Tower (c. 1450), the Porter's Lodge ( $14^{\text {th }}$ century), the entrance to the garden and the Ambulatory ( $16^{\text {th }}$ century). Keats would have seen all of these. Author's photograph

We can follow Keats's route today, walking through the streets, squares and water meadows to St Cross - and we can track him a figuratively, too, in his poems and letters. Like Wordsworth, Keats likened the composition of poetry to walking and the sensation of 'footing slow' sometimes passes directly into the rhythm and iambic 'feet' of his poetry:

There is a joy in footing slow across a silent plain,

Where patriot battle has been fought, when glory had the gain ...

There is a joy in every spot made known by times of old,

New to the feet, although the tale a hundred times be told.

('There is a joy in footing slow across a silent plain', 1-2, 5-6).

For Keats, composition was 'a regular stepping of the Imagination' that would eventually arrive at the 'new feet' of a completed poem, as Keats himself at the church of St Cross. Always for Keats a freedom to move was associated with composition - indeed, for most of his creative life he was on the road to or from locations of composition: Margate, the Isle of Wight, Canterbury, St Leonards, Box Hill, Oxford, Teignmouth, the Lake District, Scotland, Mull, Iona, Oban, Inverness, Chichester, Bedhampton, the Isle of Wight. At Winchester he worked on his epic The Fall of Hyperion; wrote a fifth act for his tragedy Otho the Great; finished his 
narrative poem Lamia; began a sonnet in French; started reading the Italian poet Ariosto; and composed 'To Autumn'. His dash to London between Friday $10^{\text {th }}$ and Wednesday $15^{\text {th }}$ September is in keeping with his extraordinary energy at this time.

If Keats was productive and relatively settled at Winchester, usually he was much more restless. When in London, he tried to get away to write; once away and on his own, he longed to be back among his brothers and city friends. Partly, perhaps, this was a way to delay putting pen to paper: 'I shall forth-with begin my Endymion', he wrote from Carisbrooke, scribbled a few lines, and then hurried back to London and on to meet his brother Tom at Margate $(L J K, \mathrm{I}, 134)$. The four books of Endymion were written in different parts of England - at the Isle of Wight, Margate, Oxford, and Box Hill - and in each of those four books, the local landscape serves as a backdrop to the story. The first book of Endymion gets underway on an April morning at Carisbrooke, with its green landscape of 'rills' and 'rushes', 'ivy banks' and 'copseclad vallies'. Two years later, the first part of Lamia was written in an identical landscape of 'rushes green', 'brakes' and 'cowslip'd lawns' - recreating classical Greece at the Isle of Wight in summer 1819. Traditionally held to be a poet of 'beauty' or 'sensuality', Keats was also a poet of local landscapes and habitations - a kinsman of Robert Burns, Charlotte Smith, William Wordsworth, John Clare, Thomas Hardy, Edward Thomas and Seamus Heaney (who acknowledged Keats's poetry as an early influence). In this chapter I investigate how Winchester, its topography and some of its historical associations may have influenced Keats during his two-months stay. That influence, I argue, is apparent in the landscape and language of Lamia, in Keats's reflections on Chatterton and the English language and, through the city's association with King Alfred, in the linguistic archaeology of 'To Autumn'. 
The second part of Lamia was written in Keats's spacious lodgings at Winchester. It opens on a summer day with two lovers, Lycius and Lamia, drowsing on their couch:

\author{
Where use had made it sweet, with eyelids closed, \\ Saving a tythe which love had open kept, \\ That they might see each other while they almost slept; \\ When from the slope side of a suburb hill, \\ Deafening the swallow's twitter, came a thrill \\ Of trumpets - Lycius started - the sounds fled, \\ But left a thought, a buzzing in his head ...
}

(II, 23-29)

The setting is supposed to be a mansion at Corinth in classical Greece, although what these lines describe is as thoroughly English as the ancient word 'tythe', denoting a tenth part, first recorded in the Laws of King Alfred c. 890-901. ${ }^{2}$ The landscape, language and antiquity of Winchester was infiltrating Keats's poem, creating its curious mingling of classical myth, mediaeval and modern. When I was writing my biography John Keats. A New Life it seemed to me that 'a thrill/ of trumpets' might have recalled the sound of a hunting horn, heard on St Catherine's 'suburb hill' or more distant Twyford Down. Likewise, the architecture of the poem's Corinthian mansion, with its 'fretted splendor of each nook and niche', is probably a reminder of gothic structures and forms in the cathedral, squares, city gate and old St Cross. Contrasting with the tranquility of Cathedral Close, Corinth's 'thronged streets' and 
carriage wheels with 'dazzling spokes' mingle Grecian grandeur with life in a busy English provincial city on Winchester's Silver Hill or Southgate Street. As he 'turned', 'passed on' and 'passed through' Winchester, Keats also found his way into the imagined city of his poem.

Winchester's fusion of ancient and modern is echoed in Keats's language. A 'suburb hill', for instance, sounds like a modern phenomenon although the word 'suburb' is classical in origin, deriving from Latin suburbium, the country near a city; 'hill' comes from the Old English 'hyll' first cited in Aelfric's Homilies, circa 1000, when Winchester Cathedral was already more than three hundred years old. The word 'swallow' is almost as old as Winchester cathedral, dating from around 700; and 'twitter' predates Chaucer. Dryden has 'Swallows twitter on the Chimney Tops'; Gray's Elegy has 'The swallow twittr'ing from the straw-built shed', and Keats's great Winchester poem 'To Autumn' has 'Gathering swallows twitter in the sky'. Lastly a 'tythe' is a tenth part, and a mediaeval tax 'the tenth part of the annual produce of agriculture being a due or payment for support of the priesthood and religious establishments'. The verbal form 'to tythe' was first used, at Winchester, in King Alfred's translation of Pope Gregory's Pastoral Care (c. 897): 'ge tiogoðiað eowre mintan \& eowerne dile \& eowerne kymen'. ${ }^{3}$

'I always somehow associate Chatterton with autumn', Keats tells us from Winchester, 'He is the purest writer in the English Language. He has no French idiom, or particles like Chaucer - 'tis genuine English Idiom in English words. ... English ought to be kept up' (LJK, II, 167, 212). This is a curious claim, because to many of Keats's contemporaries Thomas Chatterton was a notorious forger - neither 
'pure' nor 'genuine' and most particularly so in his use of the English language. Chatterton was the eighteenth-century English poet (1752-1770) who back-dated himself 300 years and invented a fifteenth-century monk called Thomas Rowley, whose poetry manuscripts Chatterton claimed to have discovered in a muniment storeroom at St Mary Redcliffe, Bristol. Through this Rowley persona, Chatterton created his own version of ancient verse, transcribed on old vellum using mediaeval calligraphy. Robert Browning thought that this medieval invention signaled a genuine creative genius, tragically forestalled when Chatterton killed himself in a London garret. Aged just 17 years and nine months at his death, Chatterton became for the Romantics an archetype of neglected genius; Coleridge wrote a 'Monody on the Death of Chatterton' in 1794, and was still tinkering with it in the 1830s; Robert Southey published an edition of Chatterton's poems; to Wordsworth Chatterton was the 'marvellous boy' who embodied the dangers of living too intensely in the imagination. The painter Henry Wallis exhibited 'The Death of Thomas Chatterton' at the Royal Academy in 1856.

Keats's 'Poetic Romance' Endymion was 'Inscribed to the Memory of Thomas Chatterton', and he most likely associated Chatterton with autumn because of these lines of poetry by Thomas Rowley:

Whanne Autumpne blake and sonne-brente doe appere,

With hys goulde honde guylteynge the falleynge lefe,

Bryngeynge oppe Wynterr to folfylle the yere,

Beerynge uponne hys backe the riped shefe;

Whan al the hyls wythe woddie sede ys whyte; 
Whanne lvynne-fyres and lemes do mete from far the syghte;

Whann the fayre apple, rudde as even skie,

Do bende the tree unto the fructyle grounde;

When joicie peres, and berries of blacke die,

Doe daunce yn ayre, and call the eyne arounde;

Thann, bee the even foule, or even fayre,

Meethynckes mie hartys joie ys steynced wyth somme care. ${ }^{4}$

This is from Chatterton's poem 'Aella', and a search in the online $O E D$ for most of its words produces: 'Check your search and try again'. As a correspondent to the Morning Chronicle observed, such words 'may be found in the modern antiques of Chatterton', but not in the works of earlier writers. ${ }^{5}$ Chatterton's Old English is an invented language, and it could be said to be 'pure' in that sense - but it is certainly not, as Keats suggested, 'genuine English Idiom in English words'.

Such claims about Chaucer, Milton and Chatterton reflected a popular view that Chaucer's 'French idiom' had come in after the Norman Conquest of 1066. This was often noted in studies of the English language with which Keats was familiar. For example, Joseph Priestley's Rudiments of English Grammar frequently cites and cautions against 'French idiom'. 'If I have done any essential service to my native tongue', Priestley writes, 'I think it will arise from my detecting in time a very great number of gallicisms, which have insinuated themselves ... and which, in my opinion, tend greatly to injure the true idiom of the English language'. ${ }^{6}$ Keats agreed: in his opinion, Thomas Chatterton's poems had revived an earlier, uncontaminated form of 
English associated with Anglo-Saxon culture and, in Winchester particularly, with King Alfred.

By Keats's time, King Alfred had long been regarded as a founder of the English nation, the legislator of English liberties and laws, a translator and a significant poet in his own right. He came to be associated with civic values, education, English literature, English language, English history, English law, the Royal Navy, and the English constitution. At a more local level, too, he was a presence in the English landscape - in Winchester, and at his hiding place on Athelney in Somerset near where, in 1693, the Ashmolean Museum's famous 'Alfred Jewel' was found. A few miles from Athelney, Wordsworth and Coleridge wrote Lyrical Ballads, and Wordsworth would be a lifelong admirer of Alfred, 'at the head/ Of all who for [England's] rights watched, toiled and bled' (see his sonnet 'Young England').

John Spelman's Life of Alfred the Great - completed in 1642, published in Latin in 1678, re-Englished by Thomas Hearne in 1709 - did much to inspire eighteenth-century Alfredianism. Throughout that century a steady stream of publications and performances established Alfred as a popular national hero who was both a pattern for princes ('Rule, Britannia!') and a figurehead for radical and democratic opposition who was admired and invoked by Keats, Hunt and their circle. ${ }^{7}$ Here follows a list of the key eighteenth-century contributions to the cult of King Alfred: 
David Mallet and James Thomson, 'Alfred: A Masque', in two acts, containing the chorus 'Rule, Britannia!', performed at 'Cliffden' (Cliveden) 1 August 1740 and, as a three-act opera, at Covent Garden, 1745.

David Mallet, a new version of the above performed as 'Alfred: A Masque', London, 1751.

'Alfred the Great, A Drama for Music, new composed by Mr. Arne' performed at Covent Garden, 1753 and subsequently as 'Alfred the Great, an Oratorio', 1754.

Alfred the Great; Deliverer of his Country, a five-act tragedy performed and published at London, 1753.

'Alfred the Great: an Oratorio', libretto published in London, 1754.

Alexander Bicknell, Life of Alfred the Great, King of the Anglo-Saxons, 1777.

John Home, Alfred: a Tragedy, performed and published, 1778.

Robert Holmes, Alfred. An Ode. With Six Sonnets, 1778.

John Ryland, The Life and Character of Alfred the Great, 1784.

Alexander Bicknell, The Patriot King: or, Alfred and Alfrida. A Historical Tragedy, 1788.

Alfred: an Historical Tragedy, anonymous play, 1789.

Philip Withers, Alfred's Appeal, 1789.

John Penn, The Battle of Eddington or British Liberty. A Tragedy, 1792.

Observations on the Life and Character of King Alfred, 1794.

John O'Keefe, Alfred, or the Magic Banner, performed 1796, published 1798.

Joseph Cottle, Alfred, an Epic Poem, in Twenty-Four Books, 1800.

Henry James Pye, Alfred; an Epic Poem, in six books, $1801{ }^{8}$ 
Of these publications, one was of particular significance to John Keats: John Ryland's Life and Character of Alfred the Great (1784). Ryland was a Baptist minister, inspiring school teacher, and founder of the Enfield school Keats attended as a boy; on the bookshelves in the school library was, almost certainly, his Life and Character of Alfred the Great. In Ryland's book Keats could read about Alfred's support for frequent parliaments, his astute management of revenue, and how he divided his kingdom into shires and hundreds. There were pages on Alfred's administration of justice, his religion, the schools and colleges he founded, and his military discipline. A genuine Anglo-Saxon polymath, Alfred was a grammarian, a rhetorician, a philosopher and historian, 'the prince of Saxon poets, well skilled in music, an excellent architect and geometrician'. He was also, Ryland told Keats, an accomplished brick-maker - a detail that mattered, in that the Enfield school house was surrounded by brick fields. ${ }^{9}$

PRINTER: Ch 2, Fig 3 SHOULD GO NEAR HERE.

CAPTION Fig 3. Alfred the Great, frontispiece to John Ryland, The Life and Character of Alfred the Great (London, 1784).

For Keats, Alfred was a poet-king - 'our own Alfred', he called him, a beacon of good government during the dog-days of the Regency. ${ }^{10}$ Leigh Hunt had a portrait of him at the Vale of Health, described by Keats in Sleep and Poetry:

Great Alfred, ... with anxious, pitying eyes

As if he always listened to the sighs

Of the goaded world ... 
(Sleep and Poetry, 385-87)

In these lines from the end of Keats's poem, it is King Alfred who inspires Keats to begin his new life as a poet 'that very day' (402). And it is intriguing that the idea of Alfred immediately leads Keats to an ancient English word 'goad' - 'gád' - a rod or stick; the word dates from the early $8^{\text {th }}$ century (OED: year 725). As we will see in a moment, this was not the only instance of Keats at Winchester turning back to a 'purer' English language associated with King Alfred's time.

It might be objected, I suppose, that everyone has heard of King Alfred and that there was nothing remarkable in Keats having done so. That's true; still, it is extraordinary how frequently Leigh Hunt, poet and editor of The Examiner newspaper, championed King Alfred as a founder of English liberties. Month by month, Keats could read about Alfred in The Examiner:

19 June 1808: 'the chief blessing of our immortal Alfred, the Trial by Jury'. 28 August 1808: 'Alfred, the truly Great'.

4 September 1808: 'a fair representation of the people, ... handed down to us from the immortal Alfred'.

11 September 1808: "with the exception of Alfred, not a single British Prince truly merits the title of Great'.

28 May 1809: 'Alfred, the greatest and most patriotic of kings'.

21 April 1811: 'Was it in this way that our glorious Alfred showed confidence in his Englishmen? Was it by cowardice that he preserved his throne; by desertion that he won the hearts of his people; by deputy that he fought their 
battles and participated in their patriotism? No; for his throne was not founded on an impotent bigotry; the hearts of his people were not turned from him by selfishness and corruption; their patriotism was not that of the soil only, but of gentleness and high interests, of conscious dignity in their place and happiness in their possessions'.

17 January 1813: 'On the downfall of the Danes, who formerly surveyed our districts, Alfred erected the lasting fabric of our liberties'.

9 July 1815: 'King ALFRED stands at the head of all the great freemen whom England has produced: - MILTON may be placed at the head of all her poets and others, who have loved liberty as well from the loftiness of imagination as from a sense of pubic duty ...'.

9 March 1817: 'You are descendants of Alfred, the wise, the all accomplished, the noble-hearted, who fought fifty-six pitched battles for real liberty, and who said in his will that his countrymen ought to be free as their own thoughts'. ${ }^{11}$ 15 March 1818: 'Robin [Hood] was the very Alfred of banditti'.

In these years of national alarm King Alfred was invoked in The Examiner as a presider of the nation, a guardian of 'our liberties'. Keats's reference to him in 'Sleep and Poetry' may have been little more than an acknowledgement of liberal sympathies shared with his host Leigh Hunt: both men admired Alfred as 'the greatest and most patriotic of kings'. As months passed, however, there is evidence that Keats was becoming more imaginatively engaged with Alfred's example as a poet, translator and champion of the English language. That evidence is to be found in 'To Autumn' and in the hinterland surrounding its composition. 
Keats had opened his epic poem Hyperion in a hushed, uneasy truce following war between Titans and Olympians, an anxious interim that spoke to the national mood after the Battle of Waterloo. The Bourbon monarchy had been restored in France, and Britain, exhausted by twenty-five years of war, had sunk into a brooding calm. 'It is quiet', Hunt wrote in the Examiner, 'it seems peaceable to us here in Europe; it may even continue so, as far as any great warfare is concerned' - but he detected signs of further change. ${ }^{12}$ Keats had already indicated that his epic would project a path of progress in the realm of myth and, by implication, in the modern world. In the vanguard of those changes, leading the country into the future, would be his poet-hero Apollo - an Olympian partner for King Alfred in the English tradition.

Then came the tragedy of Peterloo. On Monday $16^{\text {th }}$ August $1819-$ just after Keats arrived in Winchester - a crowd gathered at St Peter's Fields, Manchester, to hear 'Orator' Henry Hunt call for political reform. They assembled peaceably, The Examiner reported, until the local militia surged into the crowd at full gallop to disperse it, trampling many underfoot and killing at least twelve people. This outrage was swiftly and widely reported in newspapers: the Manchester Mercury, for instance, observed the on the morning of the $17^{\text {th }}$ that 'the necessary ardour of the troops in the discharge of their duty has led, we lament to say, to some fatal and a many very serious accidents'. ${ }^{13}$ Keats would enter the story during his three-day visit to London in mid-September, when he watched Henry Hunt arrive to a hero's welcome in the city. ${ }^{14}$

Returned from London to his lodgings in Winchester, Keats was alone, confronted by ill-health and, as he thought, his inability to attain what he termed 'the 
height': 'I am obliged continually to check myself and strive to be nothing' ( $L J K$, II, 147). Money, or rather the lack of it, was a perennial problem; his letters seemed to be going astray, and bad news had come from America - his brother George's business had failed. Such was the troubled backdrop of 'To Autumn': while none of it would be expressed or confronted directly in his poem, the poem's scenes of transience, change and continuity may quietly and indirectly address those contexts as Keats follows King Alfred and gathers a hoard of old English words to show us how 'English', and post-Waterloo/ post-Peterloo England, 'ought to be kept up'.

Keats's own introduction to his poem is famous: 'How beautiful the season is now - How fine the air. A temperate sharpness about it. Really, without joking, chaste weather - Dian skies - I never lik'd stubble fields so much as now ... Somehow a stubble plain always looks warm - in the same way that some pictures look warm this struck me so much in my Sunday's walk that I compos'd upon it' (LJK, II, 167):

Season of mists and mellow fruitfulness,

Close bosom-friend of the maturing sun;

Conspiring with him how to load and bless

With fruit the vines that round the thatch-eves run;

To bend with apples the moss'd cottage-trees,

And fill all fruit with ripeness to the core;

To swell the gourd, and plump the hazel shells

With a sweet kernel; to set budding more,

And still more, later flowers for the bees,

Until they think warm days will never cease,

For summer has o'er-brimm'd their clammy cells. 
Who hath not seen thee oft amid thy store?

Sometimes whoever seeks abroad may find

Thee sitting careless on a granary floor,

Thy hair soft-lifted by the winnowing wind;

Or on a half-reap'd furrow sound asleep,

Drows'd with the fume of poppies, while thy hook

Spares the next swath and all its twined flowers:

And sometimes like a gleaner thou dost keep

Steady thy laden head across a brook;

Or by a cyder-press, with patient look,

Thou watchest the last oozings hours by hours.

Where are the songs of spring? Ay, where are they?

Think not of them, thou hast thy music too, -

While barred clouds bloom the soft-dying day,

And touch the stubble-plains with rosy hue;

Then in a wailful choir the small gnats mourn

Among the river sallows, borne aloft

Or sinking as the light wind lives or dies;

And full-grown lambs loud bleat from hilly bourn;

Hedge-crickets sing; and now with treble soft

The red-breast whistles from a garden-croft;

And gathering swallows twitter in the skies.

'Autumn'; 'Season ...'; 'fruitfulness'. Keats opens his poem in the 'French idiom' that, following Hunt, he associated with Chaucer. The word autumn is partly a 
borrowing from Anglo-Norman and Middle French autompne; 'season' derived from the Old French seson, indeed, the word had been used by Chaucer in his 'Prologue' to the Canterbury Tales: 'Bifil that in that seson on a day,/ In Southwerk at the Tabard as I lay ...' ${ }^{15}$ Keats, a former resident of Southwark who owned an old 'black Letter Chaucer', would have noted this ( $L J K, \mathrm{I}, 276)$. What follows in 'To Autumn' moves away from these Anglo-French words as Keats uncovers layer upon layer of the "true idiom of ... English' that predated those other fourteenth-century French imports 'maturing', 'conspiring', and 'gourd'. ${ }^{16}$ Sun, bless, thatch, eve, moss, ripeness, apple, hazel, kernel, bee, warm, clammy, oft, amid, winnow, reap, swath, brook, hook, cloud, gnat, sallow, bleat, bourn, hedge, croft, gather and swallow: such is Keats's Winchester lexicon - a sequence of sturdy old words, pared down, most of them monosyllables that Keats associated with 'genuine English Idiom'. The oldest of them are 'hook', 'sallow', 'oft', 'gather' and 'swallow', dating according to the $O E D$ from as far back as c. 700, around fifty years after the founding of Winchester cathedral. Slightly later is 'hedge', from 785; 'winnow' and 'gnat' are ninth-century words; 'sun', 'swath' and 'brook' are dated to 888 when they are first recorded, at Winchester, in King Alfred's translation of Boethius's Consolation of Philosophy. 'Bourn', one of Keats's favourite words meaning a stream or brook, can be traced to its first recorded use in William Langland's fourteenth-century alliterative poem Piers Plowman: 'I was wery forwandred and wente me to reste/ Under a brood banke by a bourne syde'. ${ }^{17}$ Keats had not read, perhaps had not even heard of Piers Plowman, yet his phrase 'hilly bourn' seems to recall, very precisely, Langland's opening lines 'on Malverne hilles/ ... by a bourn syde'. Exactly: a 'hilly bourn'. 
Poised mid-way between summer and winter, 'To Autumn' holds its languages in fine equilibrium, as a residual 'French idiom' mingles with and is supplanted by an unmistakably English register from the age of 'the old poets' and earlier still. Indeed, as we have just seen, the poem is loaded with language that was coeval with Winchester cathedral. This richly imagined process of linguistic recovery is sustained throughout, into the third stanza and up to the poem's final line, where those two ancient words 'gathering swallows' embody the whole poem's native inspiration while keeping at bay Keats's fateful word 'gone'. In the aftermath of Peterloo, perhaps these old English words would - intuitively, instinctively - quicken ideas of the liberties, rights, and freedoms associated with King Alfred and so recently violated in Manchester. A lock of hair is 'soft-lifted' to float free on a 'winnowing wind'; a furrow is abandoned 'half-reap'd'; the gleaner - an archetype of poverty and exclusion - gathers into a figure of steady purpose.

As we read 'To Autumn' now we are aware that it was the last major poem Keats would write. Still to come were several poems to Fanny Brawne and his strange, unfinished comic narrative 'The Cap and Bells', although illness ensured that none of these were poems of genius comparable with 'To Autumn'. The poem has entered England's national consciousness: every September, as the 'season of mists' returns to the English landscape, the first lines of Keats's poem appear in newspapers and on weather reports. The poem has been read on BBC Radio 4's 'Today' programme to mark the autumn equinox. For us, it is John Keats, not Chatterton, who is associated with Autumn - indeed it has been suggested that 19 September should become 'John Keats Day'. Partly this is explained by the linguistic magic of the poem itself, the brilliance of Keats's verbal painting; yet while it is evocatively textured and 
timelessly poignant, it is also curiously elusive. Who or what is the figure glimpsed in the second stanza 'sitting careless', or 'sound asleep', 'like a gleaner' and 'with patient look'? Is it a spirit of the season? A pagan goddess, Ceres? A shade of King Alfred, summoned into this granary of old English words, or young Thomas Chatterton? Equally, for all its 'mellow fruitfulness' the poem has some chilly corners - those 'clammy cells', for instance, and the sequence of words in the third stanza running from 'soft-dying day' through 'wailful' and 'mourn' to 'lives or dies' and the 'full-grown lambs' who were 'hilly born' up on Twyford Down but are now sheep ready for market and whatever may follow - though Keats would not let his poem say that.

Keats's soundings of England continue to surprise and delight, as does the way he has placed a piece of heavy farm machinery right at the poem's heart - a 'cyder-press'. Massive, immovable, as big as a barn - its 'last oozings' will begin to ferment as another of the autumnal ripenings evoked by the poem. There was a cider press at St Cross, and perhaps Keats saw it on one of his water-meadow wanderings out of Winchester. Some of my students at St Andrews University think that the cyder-press is a reminder of tragic crushings and tramplings at Peterloo. Or is the cyder-press a reminder of old Saturn in Hyperion, a motionless presence around which the life of the poem arranges itself while 'with patient look/ Thou watchest ... hours by hours'? I sometimes wonder if, at this point, Keats had written his poem to a momentary pause, a pause extending hours by hours by hours beyond our world of time and transitions .... until Keats looked up at the blank side of a house, turned his page, and completed the third stanza. That must remain as a speculation, yet the poem's evocation of timeless change surely has something to do with the antiquity 
and apparent changelessness of Winchester itself, as Keats footed through its ancient streets late in September 1819, through one of the old city gates to College-Street, across some water meadows, and out of sight?

\section{Works Cited}

Chatterton, Thomas, The Works of Thomas Chatterton, 3 vols (London: T. N. Longman and O. Rees, 1803).

Chaucer, Geoffrey, The Complete Works of Geoffrey Chaucer, ed. F. N. Robinson, 2nd edn (London and Oxford: Oxford University Press, 1974).

The Examiner.

Keats, John, The Letters of John Keats 1814-1821, ed. Hyder Edward Rollins (2 vols, Cambridge, MA: Harvard University Press, 1958).

—, The Poems of John Keats, ed. Jack Stillinger (London: Heinemann, 1978).

Langland, John, The Vision of Piers Plowman. A Critical Edition of the B-Text, introd. A. V. Schmidt (London, Melbourne, Toronto: J. M. Dent, 1978).

The Manchester Mercury.

Miles, Louis Wardlaw, King Alfred in Literature. A Dissertation (Baltimore: John Murphy, 1902).

The Morning Chronicle.

The Oxford English Dictionary.

Parker, Joanne, 'England's Darling': The Victorian Cult of Alfred the Great (Manchester: Manchester University Press, 2007).

Priestley, Joseph, Rudiments of English Grammar, Adapted to the Use of Schools, 3rd edn (London: J. and F. Rivington, 1772). 
Roe, Nicholas, 'English Restored: John Keats's To Autumn', Essays in Criticism, 67 (July 2017): 237-58.

—, John Keats. A New Life (New Haven and London: Yale University Press, 2012).

Ryland, John, The Life and Character of Alfred the Great (London: Charles Dilly and John Stockdale, 1784).

Turley, Richard Marggraf, 'Objects of Suspicion: Keats, "To Autumn” and the Psychology of Romantic Surveillance', John Keats and the Medical Imagination, ed. Nicholas Roe (London: Palgrave, 2018).

1 For the history of Winchester Cathedral see http://www.winchestercathedral.org.uk/our-heritage/our-history/ [Date of access: 20 November 2017].

${ }^{2} O E D$, tenth, adj. and n., A 2 a. 'Pine teoðan sceattas \& pine frumripan..agif pu Gode'.

${ }^{3}$ OED, tithe, v. 2 b.

4 'Aella', The Works of Thomas Chatterton, 3 vols (London: T. N. Longman, 1803), II, 218-19.

${ }^{5}$ Morning Chronicle (13 November 1818).

${ }^{6}$ Rudiments of English Grammar, Adapted to the Use of Schools, 3rd edn (London: J. and F. Rivington, 1772), x-xi. For the possibility that this book was used in teaching at Keats's Enfield school, see my essay 'English Restored: John Keats's To Autumn', Essays in Criticism, 67 (July 2017): 249.

${ }^{7}$ See the overview of 'Turning a king into a hero' in Joanne Parker's study, 'England's Darling': The Victorian Cult of Alfred the Great (Manchester: Manchester University Press, 2007), pp. 60-65. 
${ }^{8}$ The titles in this list of Alfrediana are drawn from Louis Wardlaw Miles, King Alfred in Literature. A Dissertation (Baltimore: John Murphy, 1902).

9 'He introduced the art of brick-making, and built his own houses of these materials'; John Ryland, The Life and Character of Alfred the Great (London: Charles Dilly and John Stockdale, 1784), 13, 19-20.

10 'To George Felton Mathew', 67.

${ }^{11}$ The detail about 'fifty-six pitched battles' comes from Ryland's Life and Character of Alfred the Great, 12: 'He fought fifty-six set battles, by sea and land'.

${ }^{12}$ The Examiner (3 January 1819).

13 'Fatal Results', The Manchester Mercury (17 August 1819).

${ }^{14}$ See in Richard Marggraf Turley, 'Objects of Suspicion: Keats, "To Autumn" and the Psychology of Romantic Surveillance', John Keats and the Medical Imagination, ed. Nicholas Roe (London: Palgrave, 2018), 173-206.

15 'General Prologue' to The Canterbury Tales, 19-20, The Complete Works of Geoffrey Chaucer, ed. F. N. Robinson, 2dn edn (London and Oxford: Oxford University Press, 1974).

${ }^{16}$ OED has 'mature' partly from Middle French 'maturer'; 'conspire' from French 'conspirer'; and 'gourde' from the French 'gourde'.

17 'Prologue', 7-8, The Vision of Piers Plowman. A Critical Edition of the B-Text, introd. A. V. Schmidt (London, Melbourne, Toronto: J. M. Dent, 1978), 1. 